Ann. Biol. anim. Bioch. Biophys., 1979, 19 (5), 1537-1545.

\title{
Steroïd production by bovine follicles in vitro : influence of size, stage of cycle and culture system
}

\author{
par Th. A. M. KRUIP, S. J. DIELEMAN, R. M. MOOR * \\ Clinic for Obstetrics, A. I. and Reproduction, \\ Veterinary Faculty, State University, Utrecht, \\ Yalelaan 7, 3508 TD Utrecht, The Netherlands. \\ * A. R. C. Instifute of Animal Physiology, \\ Animal Research Station, \\ 307 Huntingdon Road, Cambridge, U. K.
}

Summary. Non-atretic bovine follicles of varying sizes and obtained at different stages of the cestrous cycle were cultured for $24 \mathrm{hrs}$, (1) on grids in a conventional static system, (2) in rolling tubes or (3) in a continuous flux system ; after culture steroids were determined in the culture media. For comparative purposes determinations were also made of the profile of steroids secreted into the follicular fluid by follicles in vivo.

Small (2.0-5.0 $\mathrm{mm}$ in diameter) sized follicles in vivo secreted high levels of testosterone, lower amounts of progesterone and little amounts of cstradiol-17 $\beta$ into the follicular fluid. The profile of steroids secreted by this class of follicles in vitro depended upon the culture system used. In the static and rolling tube systems the small sized follicles secreted steroids in a pattern similar to that in the follicular fluid in vivo in this respect that testosterone is the main steroid secreted. An entirely different pattern, dominated by high cestradiol-17 $\beta$ levels, was produced when these follicles were culfured in the continuous flux system.

Medium (5.1-8.0 $\mathrm{mm}$ in diameter) sized follicles in vivo secreted nearly equal amounts of the three steroids mentioned. Also in this class of follicles the steroid production in vitro was dependent of the culture system used. In the static and rolling tube systems the medium sized follicles secreted mainly testosterone, less cestradiol-17 $\beta$ and a small amount of progesterone. In the continuous flux system the medium sized follicles secreted mainly cstradiol- $17 \beta$, little testosterone and a very small amount of progesterone. These patferns are different to those in the follicular fluid in vivo.

Large follicles (>8.1 $\mathrm{mm}$ in diameter) in vivo secreted high levels of œstradiol-17ß, less progesterone and testosterone. Cultured in the continuous flux system these follicles secreted mainly œstradiol-17 $\beta$ and very little testosterone and progesterone, whereas cultured in the rolling tube system these follicles produced also mainly cestradiol-17 $\beta$ as well as a substantial amount of testosterone.

In vivo as well as in vitro the day of cycle appeared to be of influence on the steroid levels produced but the number of follicles in each group is too small to draw any definite conclusions. More follicles of each class have to be sampled and cultured.

Postal address : Clinic for Obstetrics, A. I. and Reproduction, Veterinary Faculty, State University Utrecht, Yalelaan 7, 3508 TD Utrecht, The Netherlands.

Annales de Biologie animale. - 1979 


\section{Introduction.}

The importance of steroids in the full maturation of mammalian oocytes is now apparent (Moor, 1978). It has, for example, been shown that oocytes matured in follicles in sheep in the absence of an adequate level of œstrogen undergo nuclear change but are devoid of subsequent developmental capacity (Moor and Trounson, 1977). The addition of œstradiol-17 $\beta$ * to such oocytes during the early stage of maturation confers upon them the ability to undergo normal post maturational development. The precise means by which steroids act on the oocyte is unclear except that cytoplasmic maturation is most affected by the inhibition of follicular steroidogenesis (see Thibault, 1977 ; Moor, 1978). It is postulated that bovine oocytes, like those of sheep, have specific steroidogenic requirements which must be duplicated in culture in order to induce normal maturation of the oocyte. The object of our experiments has therefore been to define conditions in which the pattern of steroids produced by follicles in vitro is similar to that produced in vivo.

The size of the ovine follicle influences profoundly the profile of steroids found in the follicular fluid in vivo (Moor et al., 1978) and produced in vitro (Seamark, Moor and Mclntosh, 1974). For this reason bovine follicles of different sizes have been culfured and their steroid output measured in three entirely different culture systems. For comparative purposes measurements were also made of the steroids present in the follicular fluid of similar sized follicles in vivo.

\section{Material and methods.}

Follicles. - Ovaries from heifers and cows were collected within 20 minutes of slaughter and held at $4^{\circ} \mathrm{C}$ in a phosphate buffered saline supplemented with bovine serum albumin $(4 \mathrm{mg} / \mathrm{ml})$. Antral follicles between 2.0 and $18.0 \mathrm{~mm}$ in diameter were dissected from the ovaries using the procedure of Moor et al (1973). Only those follicles with a uniformly bright translucent appearance, extensive vascularization and a regular granulosa layer (classified as non-atretic by the criteria of Moor et al., 1978) were used both for culture and for the collection of follicular fluid. Follicular fluid was taken from 16 follicles of $2.5-5.0 \mathrm{~mm}$ in diameter (small follicles), 26 follicles of $5.1-8.0 \mathrm{~mm}$ in diameter (medium sized follicles) and 32 follicles over $8.1 \mathrm{~mm}$ in

\begin{tabular}{|c|c|}
\hline $\begin{array}{l}\text { pregnenolone } \\
\text { progesterone } \\
17 \alpha \text {-hydroxyprogesterone } \\
20 \beta \text {-hydroxyprogesterone } \\
\text { corticosterone } \\
\text { œstradiol-17 } \alpha \\
\text { œstradiol-17 } \beta \\
\propto \text { strone } \\
\propto \text { striol } \\
\text { testosterone } \\
\text { androstenedione } \\
5 \alpha \text {-dihydrotestosterone } \\
\text { androstenediol }\end{array}$ & $\begin{array}{l}=3 \beta \text {-hydroxypregn-5-ene-20-one, } \\
=\text { pregn-4-ene-3,20-dione, } \\
=17 \alpha \text {-hydroxypregn-4-ene-3,20-dione, } \\
=20 \beta \text {-hydroxypregn-4-ene-3-one, } \\
=11 \beta, 21 \text {-dihydroxypregn-4-ene-3,20 dione, } \\
=3,17 \alpha \text {-dihydroxyestra-1,3,5,(10)-triene, } \\
=3,17 \beta \text {-dihydroxyestra-1,3,5, (10)-triene, } \\
=3 \text {-hydroxyestra-1,3,5 (10)-triene- } 17 \text {-one, } \\
=3,16 \alpha, 17 \beta \text {-trihydroxyestra- } 1,3,5(10) \text {-triene, } \\
=17 \beta \text {-hydroxyandrost-4-ene-3-one, } \\
=\text { androst-4-ene-3,17-dione, } \\
=17 \beta \text {-hydroxy-5 } \alpha \text {-androstane-3-one, } \\
=3 \beta, 17 \beta \text {-dihydroxyandrost-4-ene. }\end{array}$ \\
\hline
\end{tabular}


diameter (large follicles) at different stages of the œstrous cycle and stored at $-25^{\circ} \mathrm{C}$ for steroid analysis.

Culture systems. - Intact follicles were cultured separately in one of the following three culture systems. In the first system, referred to as the static culture technique, 15 small follicles and 15 medium sized follicles were cultured on stainless steel grids in plastic Petri dishes according to the method of Moor et al. (1973). The static system was not suitable for culture of very large follicles. Large follicles were therefore not studied using this system. In the second system, referred to as the rolling tube technique, 13 small, 11 medium and 10 large follicles were placed in $20 \mathrm{ml}$ glass bottles and cultured on a rolling tube assembly (see Paul, 1970). The fluid volume in the rolling tubes is a critical factor determining the extent to which follicles survive during culture using this technique. The absolute volume of culture medium required will depend upon the size of the rolling bottle and the size of the follicle but as a general guide the medium should not cover more than half the follicle when the rolling bottle is horizontal and stationary. In the third system, the continuous flux technique, 7 small, 12 medium and 5 large follicles were cultured in continuously circulating medium by the method of Thibault, Gérard and Ménézo (1975). Enriched M199 culture medium (Moor et al., 1973) and a gas phase of 55 p. 100 oxygen, 40 p. 100 nitrogen and 5 p. 100 carbon dioxide was used in all three culture systems. No exogenous gonadotrophins or steroids were added to the culture medium. After $48 \mathrm{hrs}$ of culture, follicles were fixed in Bouin's fluid and subjected to a detailed histological classification. In addition, a small piece of corpus luteum was fixed from each animal for the dating of the day of cycle (see Donaldson and Hansel, 1965). Culture medium in which follicles had been incubated for $24 \mathrm{hrs}$ was collected and stored at $-25^{\circ} \mathrm{C}$ for steroid analysis. The presented data of the steroid analysis of the culture medium are based on those follicles with a perfect micromorphology and without picnotic nuclei in the membrana granulosa at the end of the $48 \mathrm{hrs}$ culture.

Steroid estimations. - Progesterone levels were estimated by radioimmunoassay (RIA) similar to the method described by Dieleman and Schoenmakers (1979). The antiserum (S74 B12) against 11 $\alpha$-hydroxyprogesterone-hemisuccinate BSA conjugates was raised in sheep. Oestradiol-17 $\beta$ levels were estimated by RIA largely similar to the procedure for œestrone as described by Dieleman and Schoenmakers (1979). The antiserum (OR-580) against œstradiol-17 $\beta$ 6-keto-oxime BSA conjugates, raised in sheep, was generously supplied by R. J. Scaramuzzi (1975). Testosterone levels were estimated by RIA without columnchromatography similar to the method described by Verjans et al. (1973). The antiserum (3R3TR3) against testosterone 3-ketooxime BSA conjugates, raised in rabbits, was generously supplied by de Jong (Verjans et al., 1973).

n-Hexane 96 p. 100 (p. a., J.T. Baker Chemicals, The Netherlands), fresh diethylether (p.a. Merck A. G. Darmstadt, West Germany) and n-hexane-diethylether $(4: 1, v / v)$ were used for extraction of progesterone, ostradiol-17 $\beta$ and testosterone, respectively. Steroids were purchased from Steraloids Inc. (Pawling, USA). All other chemicals were of analytical reagent grade. $\left(1,2,6,7(n)-{ }^{3} \mathrm{H}\right)$-progesterone (spec. act. $84 \mathrm{Ci} / \mathrm{mmol}),\left(2,4,6,7(\mathrm{n})-{ }^{-} \mathrm{H}\right)$-østradiol-17 $\beta$ (spec. act. $86 \mathrm{Ci} / \mathrm{mmol}$ ) and $\left(1,2,6,7(\mathrm{n})^{-3} \mathrm{H}\right)$-festosterone (spec. act. $\left.80 \mathrm{Ci} / \mathrm{mmol}\right)$, used as tracer $(10.000 \mathrm{dpm})$ in 
the RIA were obtained from Radiochemical Centre Amersham (UK) ; the tracers were subjected to routine checks for purity by gaschromatography with radiodetection and, if necessary, purified by gelfiltration on Sephadex $\mathrm{LH}-20$, according to the method described by Mikhail ef al. (1970).

A Dextran-T70 coated charcoal procedure was applied for separating bound and free fractions.

The specificity of the antisera was expressed as the percentage cross-reaction ; for the RIA of progesterone the main cross-reactions are 1.35 p. 100 for $17 \alpha$-hydroxyprogesterone, 1.90 p. 100 for $20 \beta$-hydroxyprogesterone, 0.52 p. 100 for pregnenolone, 2.27 p. 100 for $5 \alpha$-pregnane-3 $\beta$-ol,20-one, 12.89 p. 100 for $5 \alpha$-pregnane-3,20-dione, 6.82 p. 100 for $5 \beta$-pregnane-3,20-dione and 0.81 p. 100 for corticosterone ; the percentage cross-reaction of other steroids tested was less than 0.5 p. 100 (Dieleman and Schoenmakers, 1979). For the RIA of œstradiol-17 $\beta$, cross-reactions of $2.4,0.22$ and 0.19 p. 100 were found for œstrone, œstradiol- $17 \alpha$ and $œ$ striol, respectively; the percentage cross-reaction of other steroids being less than $0.1 \mathrm{p} .100$. For the RIA of testosterone the main cross-reactions are 50 p. 100 for $5 x$-dihydrotestosterone, 3.33 p. 100 for androstenedione and 7.69 p. 100 for androstenediol, as described by Verjans et al. (1973).

The intra- and interassay coefficients of variation and the limits of sensitivity for the assays were : progesterone : 11 and 12.2 p. $100(n=11)$ and 20 pg/RIA-tube, respectively; œstradiol-17 $\beta: 8$ and 9.6 p. $100(n=13)$ and 10 pg/RIA-tube, respectively; testosterone : 10 and 14 p. $100(n=8)$ and 10 pg/RIA-tube, respectively. Student's 't'test was used to determine the significance of difference between means. The results (means $\pm S E M$ ) are expressed in pmol steroids/mg protein of follicular tissue/24 hrs.

\section{Results.}

Effect of the day of cycle. - Based on the micromorphology of the corpus luteum, the follicles were subdivided into three groups. Those in group I were from animals on Day 1 to 6 of the cycle, group II were from Day 7 to 16 and group III from Day 17 to 20. Comparing the amounts and profiles of steroids secreted by small, medium sized and large follicles in the three culture systems suggested that the stage of the cycle affects steroid production in each group during the first 24 hrs after explantation but the number of follicles in each group was too small to draw any definite conclusion. In the present paper follicles within each size category have been combined without reference to the stage of the œstrous cycle at which they were obtained.

Effect of culture system. - The amount of œstradiol- $17 \beta$, testosterone and progesterone produced by follicles in the three different systems is shown in figure 1. The pattern of steroids secreted into the medium by small and medium sized follicles cultured in the static (fig. 1A) and rolling tube (fig. 1B) systems was very similar with exception of a slightly higher $(P<0.1)$ production of œstradiol-17 $\beta$ by medium sized follicles in the rolling tube system. Small and medium sized follicles in both systems produced relatively little progesterone, more œstradiol- $17 \beta$ and extremely large amounts of testosterone during the $24 \mathrm{hrs}$ culture period. By contrast steroids secreted 
into the medium by follicles in the continuous flux system (fig. 1C) showed a different pattern. Small and medium sized follicles cultured in this system secreted low but variable amounts of progesterone, relatively larger amounts of testosterone and high amounts of œstradiol- $17 \beta$. The absolute amount of œstradiol- $17 \beta$ produced by small and medium sized follicles in the flux system is much higher $(P<0.025)$ and the amount of testosterone much lower $(P<0.005)$ than in the other two systems. The differences between the rolling tube and continuous flux system were also marked when large follicles were used. The œstradiol- $17 \beta$ production in the continuous flux, which accounted for 98 p. 100 of the steroid production into the medium was much higher $(P<0.01)$ than that in the rolling tube system, where it accounted for 64 p. 100 of the steroid production, whereas the testosterone production was significantly less $(P<0.025)$ in the continuous flux than in the rolling tube. Comparing the amount of cstradiol-17 $\beta$
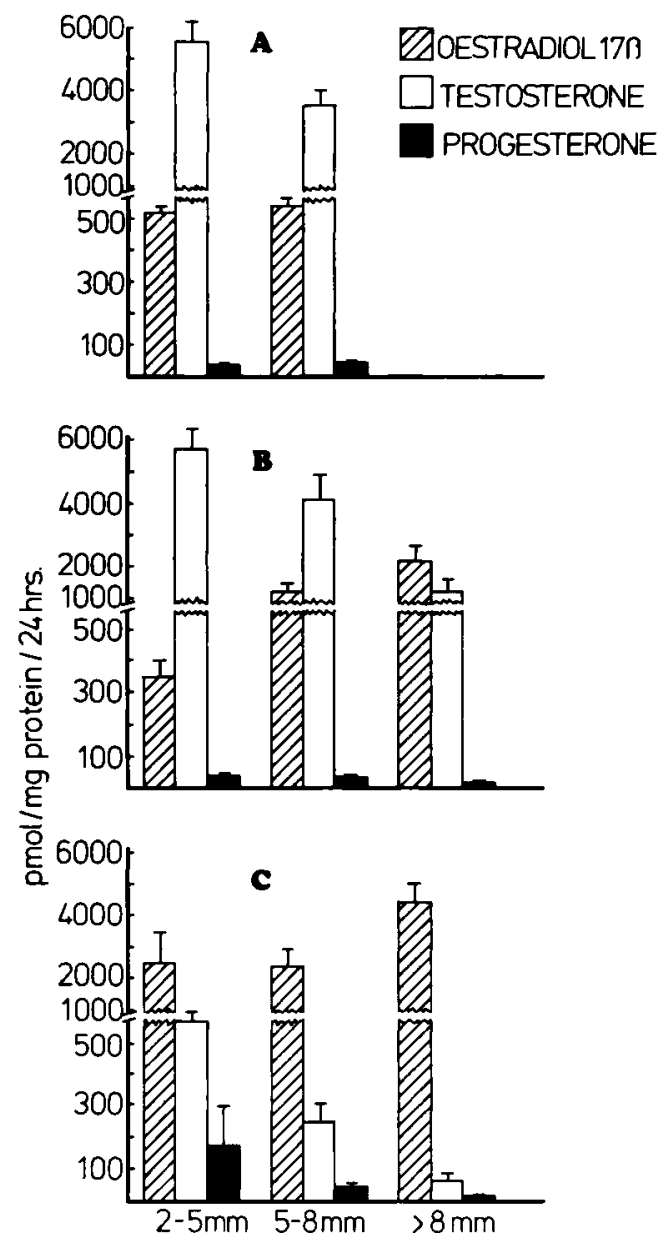

FIG. 1. - Steroid production (pmol/mg protein $24 \mathrm{hrs}$ ) by different sized bovine follicles in (A) the static, (B) rolling tube and (C) continuous flux culture system. 
produced by small and medium sized follicles in the continuous flux system with that of the large follicles in the rolling tube system surprisingly no significant difference was found.

Effect of follicle size on steroid secretion in vitro. - The progesterone and œstradiol-17 $\beta$ production in the static system (fig. $1 \mathrm{~A}$ ) did not significantly vary with the size of the follicle, whereas the testosterone production significantly $(P<0.01)$ decreased with the increase in size. In the rolling tube system (fig. 1B) the cestradiol-173 production increased significantly $(P<0.01)$ with the increase of size. Both progesterone and testosterone did not vary significantly comparing small and medium sized follicles. A marked decrease for the production of both steroids was found comparing the large follicles with the other two classes $(P<0.025$ and $P<0.005$ for the production of progesterone and testosterone respectively).

In the flux system (fig. $1 \mathrm{C}$ ) both the progesterone and testosterone production decreased significantly ( $P<0.01$ and $P<0.025$, respectively) with the increase of follicle size. The cestradiol-17 $\beta$ did not vary comparing small and medium sized follicles but comparing these classes with the large follicles a significant $(P<0.025)$ increase in the ostradiol- $17 \beta$ production in the latter was found.

Steroid concentration in the follicular fluid in vivo. - The relationship in vivo between follicle size and steroid concentration in the follicular fluid is shown in figure 2. In small sized follicles testosterone accounted for 78 p. 100 of the steroids present, whereas œstradiol-17 $\beta$ and progesterone were present in similar low amounts.

In medium sized follicles all three steroids were present in approximately equal amounts. The progesterone concentration in the follicular fluid seemed to increase slightly with an increase of size of the follicles. A marked increase in the cestradiol-17 $\beta$ concentration accompanied the increase in size, whereas testosterone decreased.

Oestradiol-17 $\beta$ dominated the steroid profile in the follicular fluid of large follicles and accounted for 79 p. 100 of the steroids. The testosterone and progesterone contents were low (7 and 14 p. 100, respectively).

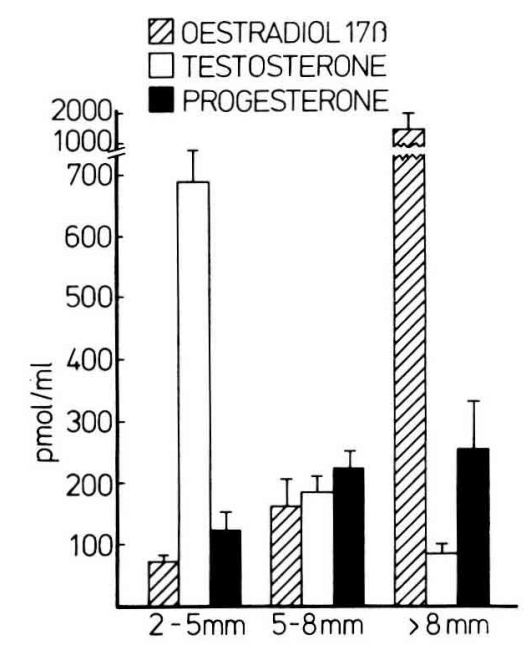

FIG. 2. - Steroid content of follicular fluid $(\mathrm{pmol} / \mathrm{ml})$ in different sized bovine follicles. 


\section{Discussion.}

The type and concentration of steroids present in the follicular fluid of bovine follicles in vivo is clearly dependent upon size and hence on the physiological development of the follicle. This finding agrees closely with that in sheep (Moor ef al., 1978). The correlation between follicle size and steroid function would currently be explained in terms of appropriate development of receptors in the theca and granulosa (see Richards, Rao and Ireland, 1978). The absence of a significant influence of the stage of the cycle on the steroidogenic function of small and medium sized bovine follicles in vivo, possible due to the limited number of follicles studied, is in accord to earlier findings in sheep. The absence of a clear cycle effect in the group of large follicles is almost certainly more apparent thant real and could be explained both by the small number of follicles examined and by the relatively imprecise method of determining the day of cycle. It is clear from the culture experiments that steroid production in vitro is influenced both by the size of the follicle explanted and by the type of the culture system utilized. The absence of significant effects of the cstrous cycle in small and medium sized follicles is consistent with the pattern of steroids in vivo (see fig. 2). However, less reliance can be placed on the findings in large follicles in view of the experiments in sheep of Seamark et al. (1974). A more detailed study of the interaction between stage of cycle and steroidogenic function in large follicles is required before reaching a conclusion on this aspect of the study.

The effect of different culture systems on follicular steroidogenesis was striking and many interesting features emerged when steroid production in the different culfure techniques was compared with that os similar sized follicles in vivo. The predominance of androgen production by small sized follicles in vivo is mirrored by the profile of steroids produced by follicles cultured in the static and rolling tube systems. By contrast, small and medium sized follicles cultured in the continuous flux system secrete steroids in a pattern that bears less relation to that observed in vivo. It must emphasized at this point that steroid production has not been the only parameter used to compare the function of small bovine follicles in different culture systems. Previous studies have reported on the metabolic activity of $2.0-5.0 \mathrm{~mm}$ in diameter follicles in the continuous flux and static culture systems (Ménézo, Gérard and Thibault, 1976 ; Ménézo ef al., 1978). These authors have shown that small bovine follicles maintained for $50 \mathrm{hrs}$ in the continuous flux system have a higher mitotic index and a 3 to 39 times greater incorporation of amino acid than those maintained on grids in the static system. It is not, however, clear which of the rates of metabolic activity observed in vitro most closely approximate the normal metabolic rate of follicles in vivo. It is further not clear whether these changes in metabolic activity in vitro can be related to the unusual profile of steroids seen in the present study when small follicles were cultured in the continuous flux system. A comparison of steroidogenesis in the large follicle group shows clearly that the continuous flux system is the most suitable method of culturing large follicles. In the rolling tube system, however, the large follicles secrete a high amount of astradiol-17 $\beta$ and a lower but substantial amount of testosterone. A partial inhibition of the aromatase system might account for the difference of this steroid profile with that in vivo. It is clear from this paper and those of Ménézo ef al. (1976, 
1978) that no single system provides ideal conditions for all aspects of follicular function in every class of bovine follicles. A careful choice of the most appropriate culture system for each specific study of follicular steroidogenesis is required. Moreover validation of the selected culture system is an important prerequisite for experiments on the function of bovine follicles in vitro. Studies on the influence of the cestrous cycle on the steroid production in vivo and in vitro are in progress.

EEC Seminar on "Ovarian stimulation and egg quality in mammals », Luynes, France, octobre 1978.

Acknowledgements. - We thank Mrs. Linda Musk for expert technical assistance. This study was supported partly by the Netherlands Organization for the Advancement of Pure Research (ZWO).

Résumé. Des follicules à antrum de vache, non atrétiques, et de différentes tailles ont été collectés à différents moments du cycle estrien et cultivés pendant 24 h soif : - sur grille en système statique conventionnel ; - en tubes courants ; - en flux continu. Les stéroïdes présents dans le milieu en fin de culture ont été dosés. Par ailleurs, ont été déterminés les profils des stéroïdes présents dans le liquide folliculaire in vivo, afin de permettre les comparaisons.

In vivo, le liquide folliculaire des petits follicules $(2,0$ à $5,0 \mathrm{~mm}$ de diamètre) contient de grandes quantités de testostérone, de petites quantités d'estradiol et de très faibles quantités de progestérone. In vitro, le profil des stéroïdes, sécrétés par cette classe de follicules dépend du système de culture utilisé. Sur grille et en tubes tournants la sécrétion de stéroïdes demeure semblable à celle observée in vivo, en ce sens que la testostérone reste le principal stéroïde sécrété. Un type de sécrétion entièrement différent, caractérisé par de hauts niveaux d'estradiol-17 $\beta$, apparaît quand la culture a lieu en flux continu.

In vivo les follicules de taille moyenne sécrètent une quantité à peu près égale des trois stéroïdes. In vitro la production de stéroïdes dépend également du type de culture. Dans le système statique ou en tubes tournants, ils sécrètent principalement de la testostérone, un peu moins d'estradiol et une petite quantité de progestérone. Dans le système à flux continu, ils produisent principalement de l'estradiol-17 $\beta$, peu de testostérone et une très petite quantité de progestérone.

In vivo les grands follicules $(>8,1 \mathrm{~mm}$ de diamètre) sécrètent de fortes quantités d'estradiol, moins de progestérone et de testostérone ; cultivés en flux continu, ces follicules sécrètent principalement de l'estradiol-17 $\beta$ et très peu de progestérone et de testostérone, tandis qu'en tubes tournants ces follicules produisent aussi principalement de l'estradiol, mais également des quantités substantielles de testostérone.

Le jour du cycle semble influencer les niveaux de stéroïdes produits aussi bien in vivo qu'in vitro, mais le nombre de follicules dans chaque groupe est trop faible pour permettre de tirer des conclusions définitives. Un plus grand échantillonnage de chaque classe de follicules doit être cultivé.

\section{References}

DIELEMAN S. J., SCHOENMAKERS H. J. N., 1979. Radio immuno assays to determine the presence of progesterone and œstrone in the starfish Asterias rubens. Gen. comp. Endocrinol. (in.press).

DONALDSON L., HANSEL W., 1965. Histological study of bovine corpora lutea. J. Dairy Science, 68, 905-909.

MÉNÉZO Y., 1976. Milieu synthétique pour la survie ef la maturation des gamètes ef pour la culture de l'œuf fécondé. C. R. Acad. Sci. Paris, Sér. D, 282, 1967-1970. 
MÉNÉZO Y., GÉRARD M., THIBAULT C., 1976. Culture du follicule de de Graaf de bovin dans un système a courant liquide et gazeuse continu. C. R. Acod. Sci. Paris, Sér. D, 283, 1309-11.

MÉNÉZO Y., GÉRARD M., SZÖLLÖSI D., THIBAULT, C., 1978. In vitro exchange between the follicle and its culture medium. Ann. Biol. anim. Bioch. Biophys., 18, 471-476.

MIKHAIL G., WU C. H., FERIN M., VANDE WIELE R. L., 1970. Radioimmunoassay of plasma œstrone and œstradiol. Steroids, 15, 333-352.

MOOR R. M., 1978. Role of steroids in the maturation of ovine oocytes. Ann. Biol. anim. Bioch.Biophys., 18, 477-482.

MOOR R. M., HAY M. F., DOTT H. M., CRAN D. G., 1978. Macroscopic identification and steroidogenic function of atretic follicles in sheep. J. Endocr., 77, 309-318.

MOOR R. M., HAY M. F., McINTOSH J. E. A., CALDWELL B. V., 1973. Effect of gonadotrophins on the production of steroids by sheep ovarian follicles cultured in vitro. J. Endocr., 58, 599-611.

MOOR R. M., TROUNSON A. O., 1977. Hormonal and follicular factors affecting maturation of sheep oocytes in vitro and their subsequent developmental capacity. J. Reprod. Fertil., 49, 101-109.

PAUL J., 1970. In Cell and tissue culture, 4th ed., p. 281, E \& S Livingstone, Edinburg and London.

RICHARDS J., RAO M. C., IRELAND J. J. 1978. Actions of pituitary gonadotrophins on the ovary 197216. In CRIGHTON D. B., HAYNES N. B., FOXCROFT G. R., LAMMING G. E. Control of ovulation. Butterworths, London.

SCARAMUZZI R. J., CORKER C. S., YOUNG G., BAIRD D. T., 1975. Production of antisera to steroid hormones in sheep, 111-122. In Steroild Immunoassay, CAMERON E. H. D., HILLIER S. G., GRIFFITHS K., Alpha-Omega, Cardiff, Wales.

SEAMARK R. F., MOOR R. M. and McINTOSH J. E. A., 1974. Steroid hormone production by sheep ovarian follicles cultured in vitro. J. Reprod. Fert., 41, 143-158.

THIBAULT C., GÉRARD M., MÉNÉZO Y. 1975. Acquisition par l'ovocyłe de lapine et de veau du facteur de décondensation du noyau du spermatozoïde fécondant (MPGF). Ann. Biol. anim. Bioch. Biophys., 15, 705-714.

THIBAULT C., 1977. Are follicular maturation and oocyte maturation independent processes ? J. Reprod. Fert., 51, 1-15.

VERJANS H. L., COOKE B. A., DE JONG F. H., DE JONG C. M. M., VAN DER MOLEN H. J., 1973. Evaluation of a radioimmunoassay for testosterone estimation. J. Steroid Biochem., 4, 665-676. 